\title{
KARAKTERISASI MINERAL TANAH JARANG IKUTAN TIMAH DAN POTENSI PENGEMBANGAN INDUSTRI BERBASIS UNSUR TANAH JARANG
}

\author{
Shinta Virdhian dan Eva Afrilinda \\ Balai Besar Logam dan Mesin, Kementerian Perindustrian \\ Jalan Sangkuriang No. 12 Bandung, Jawa Barat 40135 \\ E-mail: shinta_va@yahoo.com, afrilinda@yahoo.com
}

\begin{abstract}
ABSTRAK
Di Indonesia, mineral tanah jarang, monasit, xenotime dan zircon diasosiasikan dengan deposit alluvial timah, uranium dan emas. Mineral tanah jarang ditemukan sebagai mineral ikutan dari proses penambangan dan ekstraksi mineral timah. Pulau Bangka dan Belitung yang terletak di antara Semenanjung Malaysia dan Sumatera bagian timur diketahui sebagai deposit timah alluvial utama di Indonesia. Penelitian ini bertujuan melakukan karakterisasi dasar mineralogi dan komposisi kimia dari mineral tanah jarang yang berasosiasi dengan bijih timah. Mineral seperti monasit dan xenotim yang merupakan mineral ikutan mengandung sedikit kandungan unsur radioaktif seperti Th dan U. Hasil pengujian semi kuantitatif dari beberapa mineral (selected minerals) menggunakan EDX menunjukkan monasit memiliki rata-rata kandungan $\mathrm{Ce} 28,2 \%$, La 12,9 \%, Nd 9,7 \%, Pr 5,2 \% dan Gd 3,9\%. Sedangkan xenotim mengandung unsur utama Y 29,5\%, Dy 7,7 \% dan Gd 2,6\% Potensi pemanfaatan dan pengembangan industri berbasis tanah jarang didiskusikan dalam tulisan ini.
\end{abstract}

Kata Kunci: mineral tanah jarang, timah, monasit, xenotim.

\begin{abstract}
In Indonesia, the REE minerals, monazite, xenotime, and zircon are associated with tin, uranium and gold in alluvial deposits. REE minerals are found as by-product of tin ore mining and extraction process activities. The Bangka and Belitung Islands, located in the region between the Peninsular Malaysia and eastern region of Sumatra, are known as major alluvial tin deposits in Indonesia. This paper reports some basic characteristics of mineralogy and chemical composition of the REE minerals associated with tin ores. The main REE minerals in such ores include monazite and xenotime, which contain small amounts of radioactive elements such as thorium (Th) and uranium (U). Semi quantitative analysis of the selected minerals using EDX analysis showed that average elements contained in the monazite are Ce 28,2\%, La 12,9\%, Nd 9,7\%, $\operatorname{Pr~5,2\% ~dan~Gd~3,9\% .~}$ Furthermore, xenotime consists of Y 29,5\%, Dy 7,7\%, and Gd $2.6 \%$. Potential application and development of rare earth based industries are discussed.
\end{abstract}

Keywords: rare earth minerals, tin, monazite, xenotime .

\section{PENDAHULUAN}

Unsur-unsur tanah jarang pada tabel periodik adalah 15 logam-logam lanthanida ditambah dengan logam scandium dan yttrium, karena kedua logam tersebut memiliki sifat kimia yang hampir mirip dengan logam-logam lanthanida. Logam-logam lanthanida terdiri dari logam lanthanum, cerium, praseodymium, neodymium, promethium, samarium, europium, gadolinium, terbium, dysprosium, holmium, erbium, thulium, ytterbium dan lutetium. Unsurunsur tanah jarang merupakan kelompok unsur yang memiliki sifat elektronik, magnet, optik dan katalitik yang khusus. Unsur-unsur tanah jarang digunakan untuk aplikasi magnet permanen magnet (30\%), bidang metalurgi (20\%), fluid cracking dan autokatalis (20\%), aditif bahan gelas $(10 \%)$, pospor (10\%) dan sisanya untuk aplikasi pigmen dan keramik (Asnani dan Patra, 2013). Dalam aplikasinya penggunaan unsurunsur tanah jarang ini memerlukan kemurnian yang tinggi. Saat ini pemakaian logam tanah jarang banyak dikembangkan pada teknologi untuk menghasilkan energi terbarukan seperti pada aplikasi untuk kendaraan listrik dan turbin angin, industri teknologi informasi (IT) seperti , komputer dan telepon selular juga banyak menggunakan unsur-unsur tanah jarang 
Keberadaan unsur-unsur tanah jarang relatif banyak ditemukan pada kerak bumi. Akan tetapi karena sifat kimianya keberadaan unsur tanah jarang tersebar dan tidak terkonsentrasi di suatu tempat sehingga tidak dapat diekploitasi secara ekonomis. Walaupun begitu beberapa deposit mineral tanah jarang dapat diolah secara ekonomis yaitu mineral basnaesit, ion absoption clay, monasit dan xenotim. Cadangan logam tanah jarang yang sudah diolah terdapat di banyak negara, seperti Amerika Serikat, Australia, Brazil, China, India, Malaysia dan lain-lain. Diketahui bahwa China memiliki cadangan mineral tanah jarang yang besar dan China juga menguasai pemenuhan produksi tanah jarang dunia. Harga oksida tanah jarang dan logam tanah jarang meningkat secara drastis pada tahun 2010 dan 2011 tapi kemudian menurun pada tahun 2012. Kenaikan harga yang drastis ini karena pembatasan kuota ekspor oleh China yang menguasai hampir $97 \%$ produksi oksida tanah jarang maupun logam tanah jarang di dunia (Humphries, 2012).

Tujuan penelitaian ini adalah untuk mendapatkan karakteristik mineral logam tanah jarang yang ada di areal pertambangan PT Timah (Kepulauan Bangka) sehingga dapat dicapai sebagai acuan untuk pengolahan mineral tanah jarang skala industri dan ekonomis.

\section{TINJAUAN PUSTAKA}

\section{Mineral Tanah Jarang dan Penyebarannya di Dunia}

Klasifikasi dari deposit mineral tanah jarang dapat dilihat pada Tabel 1. Tabel 2 menunjukkan mineral-mineral tanah jarang yang dikelompokan menurut komposisi kimianya. Deposit utama dikelompokkan secara umum sebagai igneous, sedimentary, dan secondary. Gambar 1 menunjukkan penyebaran mineral tanah jarang di dunia.

Tabel 1. Klasifikasi deposit mineral tanah jarang (Kamitani, 1991)

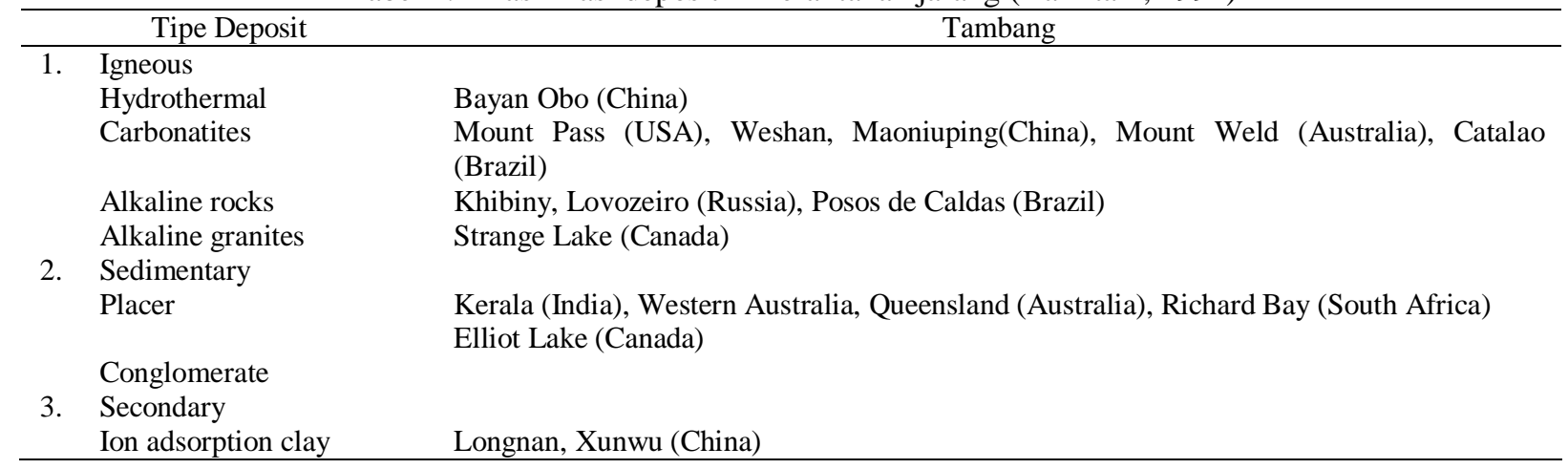


Tabel 2. Klasifikasi mineral tanah jarang berdasarkan komposisi kimianya (Kanazawa \& Kamitani, 2006)

\begin{tabular}{|c|c|}
\hline Mineral class & Mineral examples and chemical formulae \\
\hline Halides & Fluocerite-(F), $\mathrm{CeF}_{3}$ \\
\hline \multicolumn{2}{|l|}{ Carbonates } \\
\hline With fluoride & Bastnaesite, $(\mathrm{Ce}, \mathrm{La})\left(\mathrm{CO}_{3}\right) \mathrm{F}$ \\
\hline Without fluoride & Ancylite, $(\mathrm{Ce}, \mathrm{Sr}, \mathrm{Ca})\left(\mathrm{CO}_{3}\right)\left(\mathrm{OH}, \mathrm{H}_{2} \mathrm{O}\right)$ \\
\hline Borates & Braistschite, $\left(\mathrm{Ca}, \mathrm{Na}_{2}\right)_{7} \mathrm{CeB}_{22} \mathrm{O}_{43} \cdot 7 \mathrm{H}_{2} \mathrm{O}$ \\
\hline \multicolumn{2}{|l|}{ Oxides and hydrates } \\
\hline $\mathrm{AO}_{2}$-type & Cerianite, $\left(\mathrm{Ce}^{4+}, \mathrm{Th}^{4+}\right) \mathrm{O}_{2}$ \\
\hline $\mathrm{ABO}_{3}$-type & Perovskite group, $(\mathrm{Ca}, \mathrm{Ce}, \mathrm{Na}, \mathrm{Sr})(\mathrm{Ti}, \mathrm{Nb}, \mathrm{Ta}) \mathrm{O}_{3}$ \\
\hline $\mathrm{ABO}_{4}$-type & Fergusonite-Formanite, $\mathrm{Y}(\mathrm{Nb}, \mathrm{Ta}) \mathrm{O}_{4}-\mathrm{Y}(\mathrm{Ta}, \mathrm{Nb}) \mathrm{O}_{4}$ \\
\hline $\mathrm{AB}_{2}(\mathrm{O}, \mathrm{OH})_{6}$-type & Euxenite group, $(\mathrm{Y}, \mathrm{Ca}, \mathrm{Ce}, \mathrm{U}, \mathrm{Th})\left(\mathrm{Nb}, \mathrm{Ta}, \mathrm{Ti}_{2}\right)_{2} \mathrm{O}_{6}$ \\
\hline $\mathrm{A}_{2} \mathrm{~B}_{2} \mathrm{O}_{6}(\mathrm{O}, \mathrm{OH}, \mathrm{F})$-type & Pyrochlore group, $(\mathrm{Na}, \mathrm{RE}, \mathrm{K}, \mathrm{U})_{2}(\mathrm{Nb}, \mathrm{Ta}, \mathrm{Ti})_{2}(\mathrm{O}, \mathrm{OH}, \mathrm{F})$ \\
\hline Others & Hibonite, $(\mathrm{Ca}, \mathrm{Ce})(\mathrm{Al}, \mathrm{Ti}, \mathrm{Mg})_{12} \mathrm{O}_{19}$ \\
\hline \multirow[t]{3}{*}{ Phosphates, arsenates and vanadates } & Apatite, $(\mathrm{Ca}, \mathrm{RE}, \mathrm{Sr}, \mathrm{Na}, \mathrm{K})_{3} \mathrm{Ca}_{2}\left(\mathrm{PO}_{4}\right)_{3}(\mathrm{~F}, \mathrm{OH})$ \\
\hline & Monazite, $(\mathrm{Ce}, \mathrm{La}) \mathrm{PO}_{4}$ \\
\hline & Xenotime, $\mathrm{YPO}_{4}$ \\
\hline \multicolumn{2}{|c|}{ Silicates (The following groups are based on the linkage manner of tetrahedral anionic group.) } \\
\hline \multirow[t]{3}{*}{ Isolated group } & Cerite, $(\mathrm{Ce}, \mathrm{La}, \mathrm{Ca})_{9}\left(\mathrm{Fe}^{3+}, \mathrm{Mg}\right)\left(\mathrm{SiO}_{4}\right)_{6}\left[\mathrm{SiO}_{3}(\mathrm{OH})\right](\mathrm{OH})_{3}$ \\
\hline & Garnet, $(\mathrm{Ca}, \mathrm{Fe}, \mathrm{Mg}, \mathrm{Mn}, \mathrm{Y})_{3}(\mathrm{Al}, \mathrm{Cr}, \mathrm{Fe}, \mathrm{Mn}, \mathrm{Ti}, \mathrm{V}, \mathrm{Zr})_{2}(\mathrm{Si}, \mathrm{Al})_{3} \mathrm{O}_{12}$ \\
\hline & Sphene, $\mathrm{CaTiSiO}_{4}$ \\
\hline Diortho group & Allanite, $\mathrm{Ca}(\mathrm{Ce}, \mathrm{Y}, \mathrm{Ca}) \mathrm{Al}(\mathrm{Al}, \mathrm{Fe})(\mathrm{Fe}, \mathrm{Al})\left(\mathrm{SiO}_{4}\right)_{3}(\mathrm{OH})$ \\
\hline Chain group & Stillwellite, $\mathrm{CeBSiO}_{5}$ \\
\hline Ring group & Eudialyte, $(\mathrm{Na}, \mathrm{Ca}, \mathrm{Ce})_{6}(\mathrm{Zr}, \mathrm{Fe})_{2} \mathrm{Si}_{7}(\mathrm{O}, \mathrm{OH}, \mathrm{Cl})_{22}$ \\
\hline Sheet group & Gadolinite, $(\mathrm{Y}, \mathrm{Ce})_{2} \mathrm{Fe}^{2+} \mathrm{Be}_{2} \mathrm{Si}_{2} \mathrm{O}_{10}$ \\
\hline Framework group & Kainosite, $\mathrm{Ca}_{2}(\mathrm{Y}, \mathrm{RE})_{2}\left(\mathrm{Si}_{4} \mathrm{O}_{12}\right) \mathrm{CO}_{3} \cdot \mathrm{H}_{2} \mathrm{O}$ \\
\hline Others & Iimoriite, $\mathrm{Y}_{2}\left(\mathrm{SiO}_{4}\right)\left(\mathrm{CO}_{3}\right)$ \\
\hline
\end{tabular}

Bayan Obo, China adalah deposit tanah jarang terbesar di dunia. Total mineral reserve tambang yang terdapat di Bayan Obo setidaknya 1.5 milyar metrik ton $\mathrm{Fe}$ (grade rata-rata $35 \%$ ), 48 juta ton oksida tanah jarang ( grade rata-rata 6\%) dan 1 juta ton $\mathrm{Nb}$. Mineral tanah jarang yang utama adalah bastnaesite, monasit dan RE$\mathrm{Nb}$ mineral seperti aeschynite, felgusonite dan columbite. Mountine Pass, USA adalah deposit tanah jarang kedua terbesar di dunia. Deposit dalam bentuk mineral carbonatite terletak di bagian selatan California dan Nevada. Total oksida tanah jarang reserve adalah sekitar 28 juta metrik ton (grade 5-10\% REO). Produksi pada tahun 2006 turun drastis menjadi 5000 ton/tahun karena beberapa permasalahan.

Mount Weld, Australia memiliki deposit mineral tanah jarang yang berupa carbonite intrusive pipe yang memiliki diameter $3 \mathrm{~km}$. Bagian permukaan mengandung $\mathrm{Nb}-\mathrm{Ta}, \mathrm{P}$ dan konsentrasi unsur tanah jarang yang memiliki kandungan unsur radioaktif (Th dan $\mathrm{U}$ ) yang lebih rendah. Mineral utamanya adalah basnaesite. Cadangan deposit diperkirakan sekitar 917.000 ton oksida tanah jarang. Selain carbonite deposit, mineral pasir berat tipe plaser deposit juga terdapat di sepanjang Australian coast. Mineral yang terkandung meliputi rutilezircon-ilmenite pada east coast, ilmenit pada south west coast, sedangkan mineral tanah jarangnya berupa monasit dan xenotim. Tipe deposit yang lain adalah ion adsorption clay. Tipe ini terdapat di selatan China (Nanling). Secara umum batuan granit adalah batuan umum yang merupakan host dari deposit tipe ion adsorption clay. Mineral tanah jarang tipe ini diabsorpsi oleh mineral kaolin dan halloysite. Walaupun kandungan tanah jarang yang relatif rendah (0.005-0.2\%), proses penambangan dan pengolahan relatif mudah. Deposit ditambang dengan menggunakan metode open pit dan tidak membutuhkan penggerusan (milling) dan ore dressing. Selain itu kandungan radioaktifnya yang relatif rendah (Kanazawa dan Kamitani, 2006). 


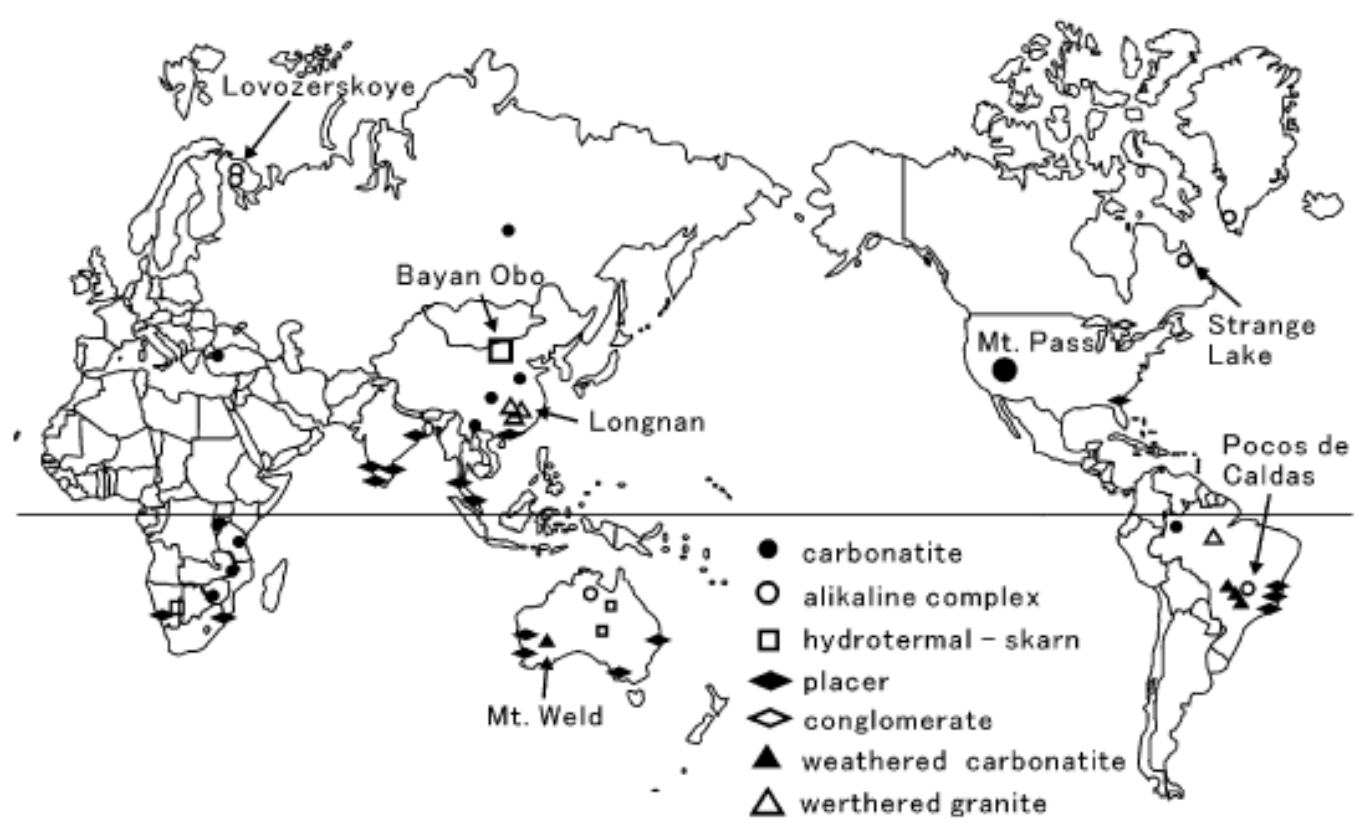

Gambar 1. Distribusi mineral tanah jarang di dunia (Yasuo Kanazawa, 2006)

\section{Potensi Unsur Tanah Jarang di Indonesia}

Keberadaan mineral tanah jarang di Indonesia diindikasikan pada daerah yang mengandung intrusi granitoid, alluvial dan plaser. Daerahdaerah yang memiliki ekstensif instrusi granitoid di Indonesia adalah Pulau Bangka dan Belitung, Kepulauan Tujuh, Singkep, Kundur, Karimun Jawa, Sumatera, Kalimantan, Pulau Sula Banggai (timur Sulawesi) dan bagian barat Papua (Johari dan Kuntjara, 1991). Mineral logam tanah jarang yang umum ditemukan di Indonesia adalah monazite dan xenotime. Di Indonesia, mineral yang mengandung tanah jarang ditemukan di daerah Bangka Belitung, bersama dengan mineral timah, dan di Kalimantan, bersama dengan mineral emas. Menurut data Pusat Sumber Daya Geologi tahun 2009, cadangan mineral monazite di Indonesia adalah lebih dari 951.000 ton (Suhkyat, 2013). Berikut adalah beberapa hasil penelitian mengenai keberadaan mineral tanah jarang di Indonesia.

\section{Pulau Bangka dan Belitung}

Keberadaan mineral tanah jarang monasit dan xenotim ditemukan sebagai ikutan dari mineral bijih timah (kasiterit). Tabel 3 menunjukkan tipikal kandungan monasit dan xenotim pada bijih timah yang belum diproses (raw sand) di Pulau Bangka dan Belitung.

Tabel 3. Tipikal kandungan monasit dan xenotim pada konsentrat bijih timah yang belum diolah di Pulau Bangka dan Belitung (Suhkyat, 2013; Irawan, 2013)

\begin{tabular}{lcc}
\hline \multicolumn{1}{c}{ Mineral } & Bangka(\%) & Belitung $(\%)$ \\
\hline Kasiterit & 40.1 & 41.0 \\
Monasit & 1.31 & 0.67 \\
Xenotim & 0.23 & 0.56 \\
\hline
\end{tabular}

2. Pegunungan Tiga Puluh (Suwargi \& Nugroho, 1991)

Hasil penelitian joint research antara Indonesia (ESDM) dengan JICA pada tahun 1989 mendeteksi anomali geokimia unsur tanah jarang pada hulu Sungai Isahan dan Sungai Sikambu di Pegunungan Tiga Puluh, Riau. Mineralisasi di hulu sungai Isahan, ditemukan singkapan pegmatit dengan urat kuarsa yang mengandung kasiterit, muskovit, turmalin, arsenopirit, pirit dan sedikit beril. Hasil analisis kimia dari contoh urat yang mengandung kasiterit, menujukkan bahwa pegmatit di sungai isahan mengadung $3,84 \%$ Sn, $0,07 \% \mathrm{~W}$, dan 0,08-0,24\% Ce. 


\section{Kalimantan Barat}

Mineral tanah jarang selain merupakan ikutan dari bijih timah dan emas, didapat juga pada bijih uranium yang terdapat di daerah Rirang, Kalimantan Barat. Jenis mineral tanah jarang yang terdapat di daerah tersebut adalah monasit (Rifandriah et.al., 2004). Dari hasil penelitian cebakan uranium di daerah Rirang, diperoleh kandungan unsur tanah jarang 5964.63 ton (Suharji et.al, 2006).

\section{Papua bagian barat}

Daerah Selatan Nabire terdapat konsentrasi tinggi dari $\mathrm{Th}, \mathrm{W}$, Ta dan $\mathrm{Nb}$ pada aliran endapan Permian Kwartisore Granite dan Utawa Diorite. Contoh dari Sungai Wami mengandung $740 \mathrm{ppm}$ Th, $25 \mathrm{ppm} \mathrm{W}, 440$ ppm Nb dan 34 ppm Ta. Kandungan U dan Ce juga terindikasi di daerah ini. Dekat jalur granit utama dari Late Permian ke Middle Triassic terdapat kandungan timah, kandungan yang rendah dari monasit, xenotim, dan ziron juga ditemukan daerah Waren Anggi Granite. (Ratman, 1986).

\section{Pulau Sula Banggai (Sulawesi)}

Karakteristik kimia dan radioaktif dari pre jurassic granite di P. Sula Banggai (sebelah Timur Sulawesi) memiliki kemiripan dengan granit di Pulau Timah (Johari \& Kuntjara, 1991).

\section{METODE PENELITIAN}

Dalam penelitian ini, contoh yang diuji adalah konsentrat bijih timah yang didapatkan dari amang plant yang berada di daerah penambangan. Gambar 2 menunjukkan proses pengolahan bijih timah di PT Timah dengan proses pemisahan dari mineral ikutannya. Dalam proses in, konsentrasi mineral yang mengandung bijih timah ditingkatkan menjadi $70 \%$ sebagai persyaratan sebelum memasuki tungku peleburan. Selain itu, proses pengolahan ini juga memisahkan bijih timah dari mineral-mineral ikurannya. Mineral tanah jarang seperti monasit dan xenotim diperoleh sebagai by-product / ikutan dari bijih timah. Pemisahan dilakukan berdasarkan sifat magnet dan sifat listrik dari mineral timah dan ikutannya. High tension separator akan memisahkan mineral berdasarkan sifat kelistrikannya yaitu menghantarkan listrik (konduktor) dan tidak menghantarkan listrik (isolator). Sedangkan magnetic separator memisahkan mineral berdasarkan sifat magnetiknya yaitu bersifat magnet (magnetic) dan tidak bersifat magnet (nonmagnetic).

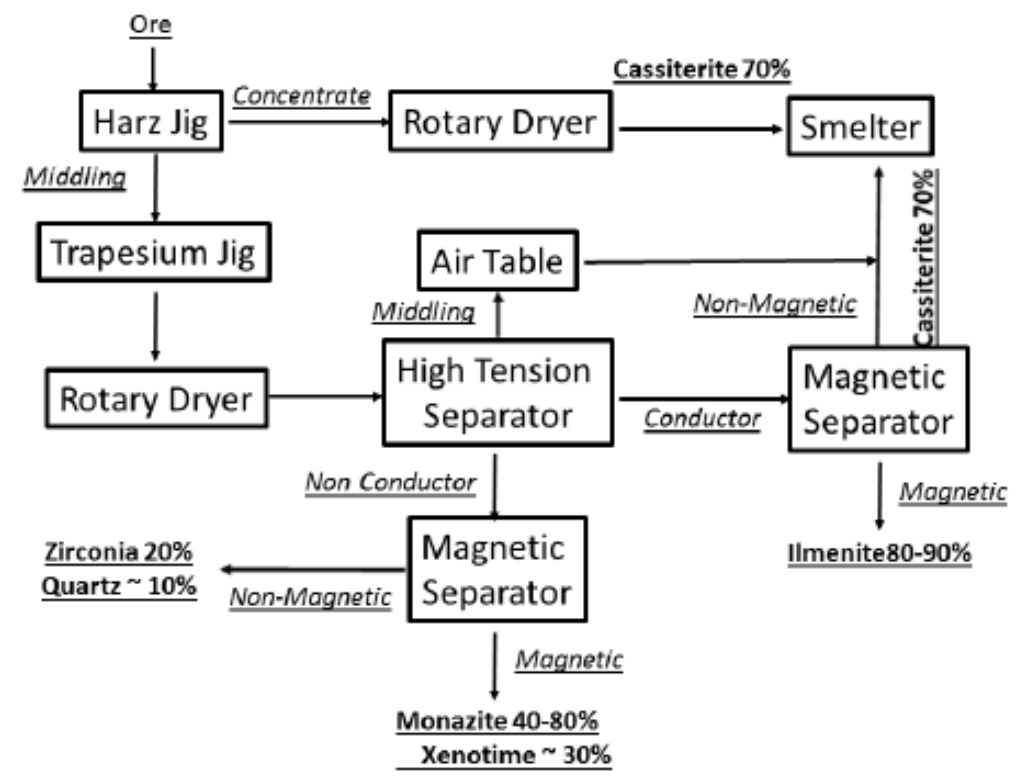

Gambar 2. Diagram alir pengolahan bijih timah untuk dipisahkan dari mineral mineral ikutan (Harjanto, Virdhian, dan Afrilinda, 2013) 


\section{HASIL DAN PEMBAHASAN}

Analisis semi kuantitatif dari konsentrat bijih timah yang belum diproses

Dalam analisis semi kuantitatif ini, contoh yang diuji adalah konsentrat bijih timah yang didapatkan dari amang plant ( daerah penambangan) yang sudah melalui proses pencucian. Konsentrat bijih timah ini selanjutnya akan dipisahkan secara fisik berdasarkan sifat magnet dan listriknya seperti yang diilustrasikan pada Gambar 2. Gambar 3 menunjukkan gambar SEM (Scanning Electron Microscope) dari konsentrat timah yang akan dipisahkan lebih lanjut. Pada konsentrat tersebut dapat diindenfikasi mineral ikutan selain mineral timah (kasiterit) yaitu monasit, xenotim, ilmenit, dan silika dengan menggunakan analisis EDX.

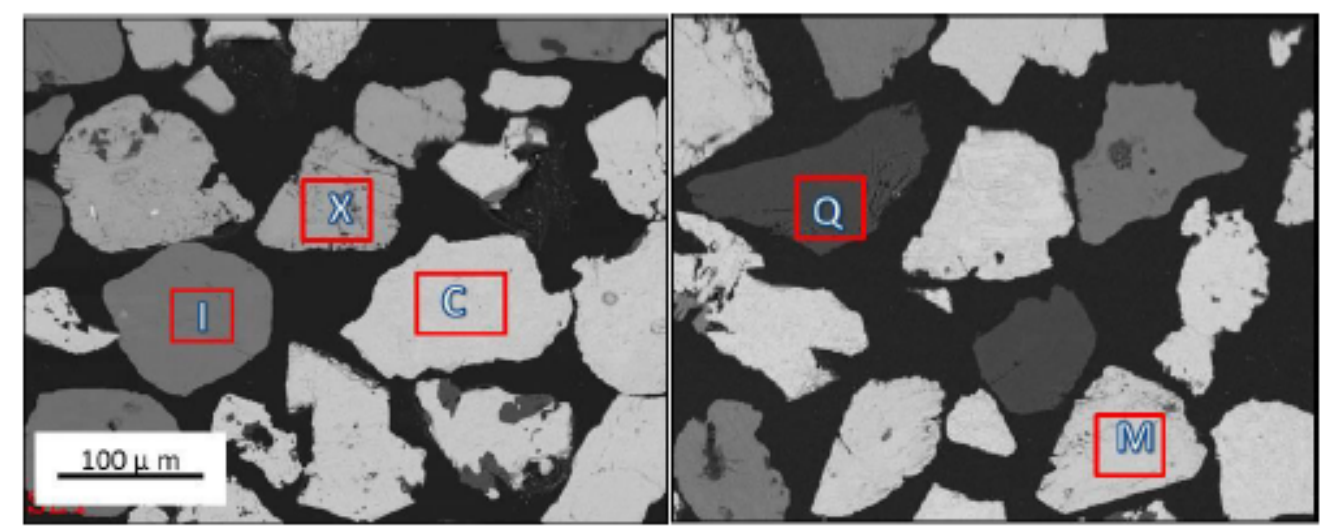

Gambar 3. Gambar back scattered SEM dari contoh konsentrat bijih sebelum diproses $\mathrm{M}=$ Monasit, $\mathrm{C}=$ Kasiterit, $\mathrm{X}=$ Xenotim, $\mathrm{I}=$ ilmenit, and $\mathrm{Q}=$ Quartz

Analisis semi kuantitatif dengan thorium. Gambar 5 menunjukkan grafik menggunakan Energy Dispersive X-Ray kandungan unsur-unsur tanah jarang dalam Spectrometer (EDX, FEI INSPECT F50, Apolox mineral monasit dan xenotim. Hasil ini EDS Analyzer) dilakukan untuk mengetahui menunjujjan bahwa monasit dan xenotim unsur-unsur yang terkandung dalam monasit dan xenotim. Gambar 4 menunjukkan hasil spectrum pengujian analisis EDX. Hasil analisis menunjukkan mineral monasit yang kaya akan cerium, lanthanum, samarium, uranium dan thorium, sedangkan xenotim mengandung yttium, gadolinium dan dysporsium, uranium dan memiliki komposisi kimia yang bervariasi. Nilai yang ditampilkan pada grafik adalah nilai ratarata dari beberapa contoh yang diuji. Monasit terindikasi memiliki kandungan mineral radioaktif seperti thorium yang lebih tinggi daripada xenotim. 

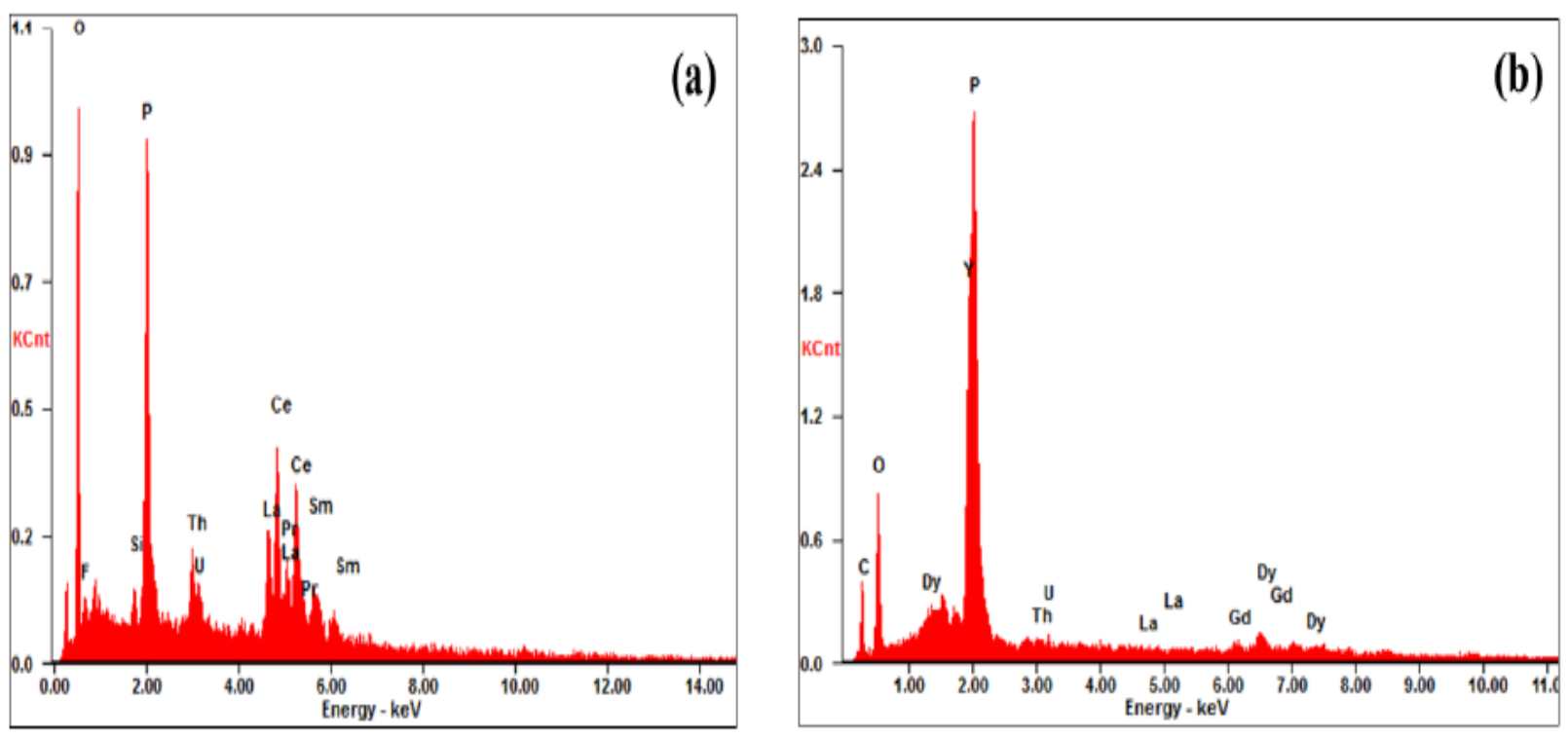

Gambar 4 Analisis elemen dari spektrum EDX, a) Monazite; b) Xenotime
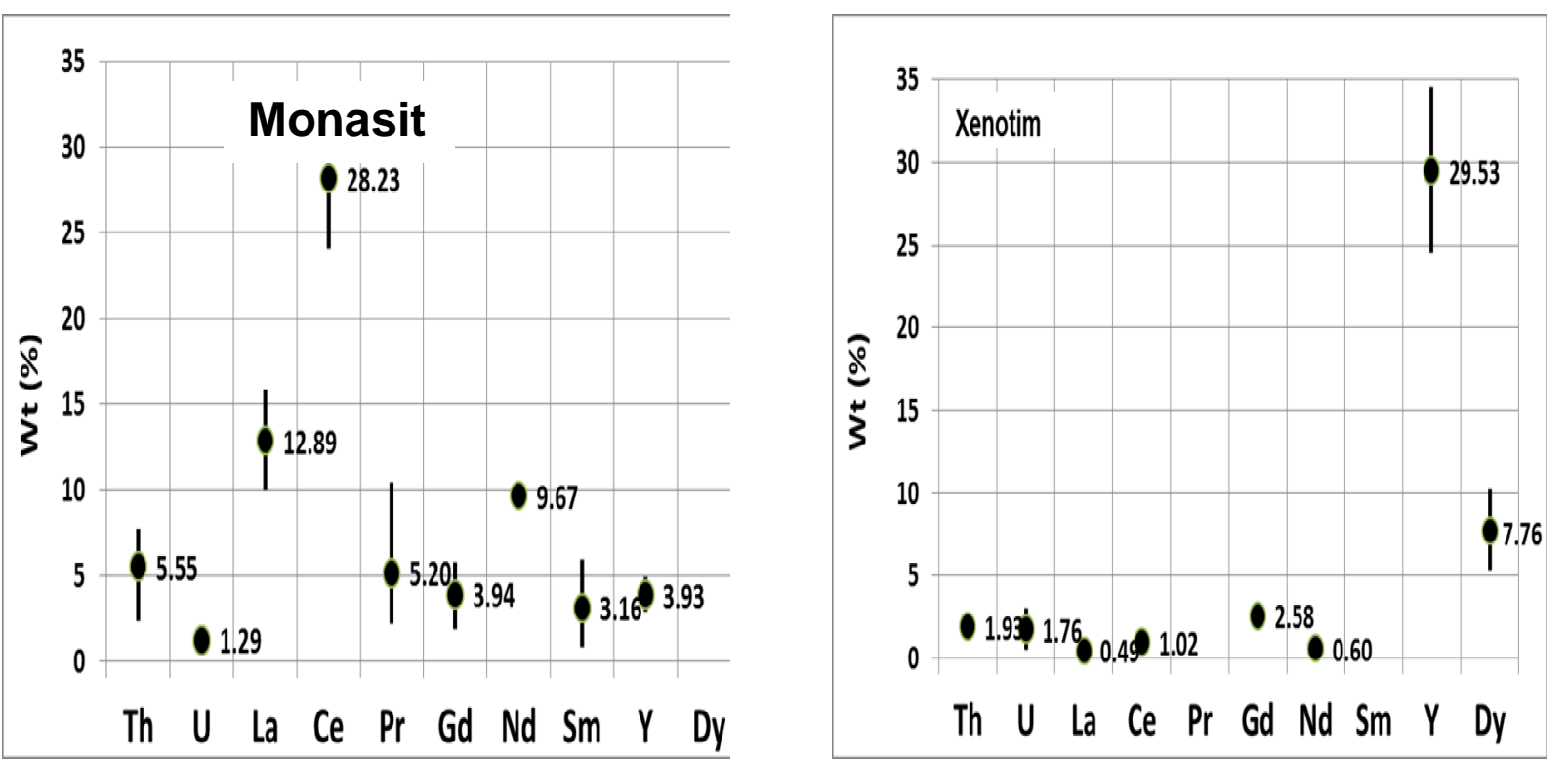

Gambar 5. Analisis semi kuantitatif menggunakan EDS dari beberapa mineral monasit dan xenotim (selected minerals)

\section{Potensi Pengembangan Industri Berbasis Unsur Tanah Jarang}

Hasil karakterisasi monasit dan xenotime menunjukkan unsur-unsur tanah jarang yang memiliki potensi untuk dikembangkan di Indonesia. Unsur-unsur tanah jarang banyak diperlukan untuk pengembangan teknologi maju yang sudah dijelaskan. Tabel 3 menunjukkan pemanfaatan unsur-unsur tanah jarang. Pada umumnya unsur tanah jarang hanya ditambahkan dalam jumlah yang sedikit untuk meningkatkan sifat dari material tersebut. Produk high end dapat diperoleh dengan melakukan proses seperti pada Gambar 6. 
Tabel 3 Aplikasi utama dari unsur-unsur tanah jarang (Humphries, 2012)

\begin{tabular}{|c|c|c|c|}
\hline $\begin{array}{l}\text { Unsur Tanah Jarang } \\
\text { RIngan }\end{array}$ & Aplikasi utama & $\begin{array}{l}\text { Unsur Tanah Jarang } \\
\text { Berat }\end{array}$ & Aplikasi Utama \\
\hline Lanthanum (La) & Hybrid engine, paduan logam & Terbium (Te) & Phosphors, magnet \\
\hline Cerium $(\mathrm{Ce})$ & $\begin{array}{l}\text { Autokatalis, pemurnian } \\
\text { petrolium, paduan logam }\end{array}$ & Dysprosium (Dy) & Magnet, hybrid engine \\
\hline Praseodymium (Pr) & Magnet & Erbium (Er) & Phosphors \\
\hline Neodymium (Nd) & $\begin{array}{l}\text { Autokatalis, pemurnian } \\
\text { petroleum, hard drives, } \\
\text { headphone, hybrid engine, } \\
\text { magnet }\end{array}$ & Yttrium (Y) & $\begin{array}{l}\text { Phosphors, red color, lampu } \\
\text { fluorescent, keramik, paduan } \\
\text { logam }\end{array}$ \\
\hline Samarium (Sm) & Magnet & Holmium (Ho) & Pewarna gelas, laser \\
\hline \multirow[t]{4}{*}{ Europium (Eu) } & $\begin{array}{l}\text { Red color untuk layar televisi } \\
\text { dan komputer }\end{array}$ & Thulium (Tm) & x-ray untuk aplikasi kedokteran \\
\hline & & Lutetium (Lu) & Katalis \\
\hline & & Ytterbium (Yb) & Laser, baja paduan \\
\hline & & Gadolinium (Gd) & Magnet \\
\hline
\end{tabular}

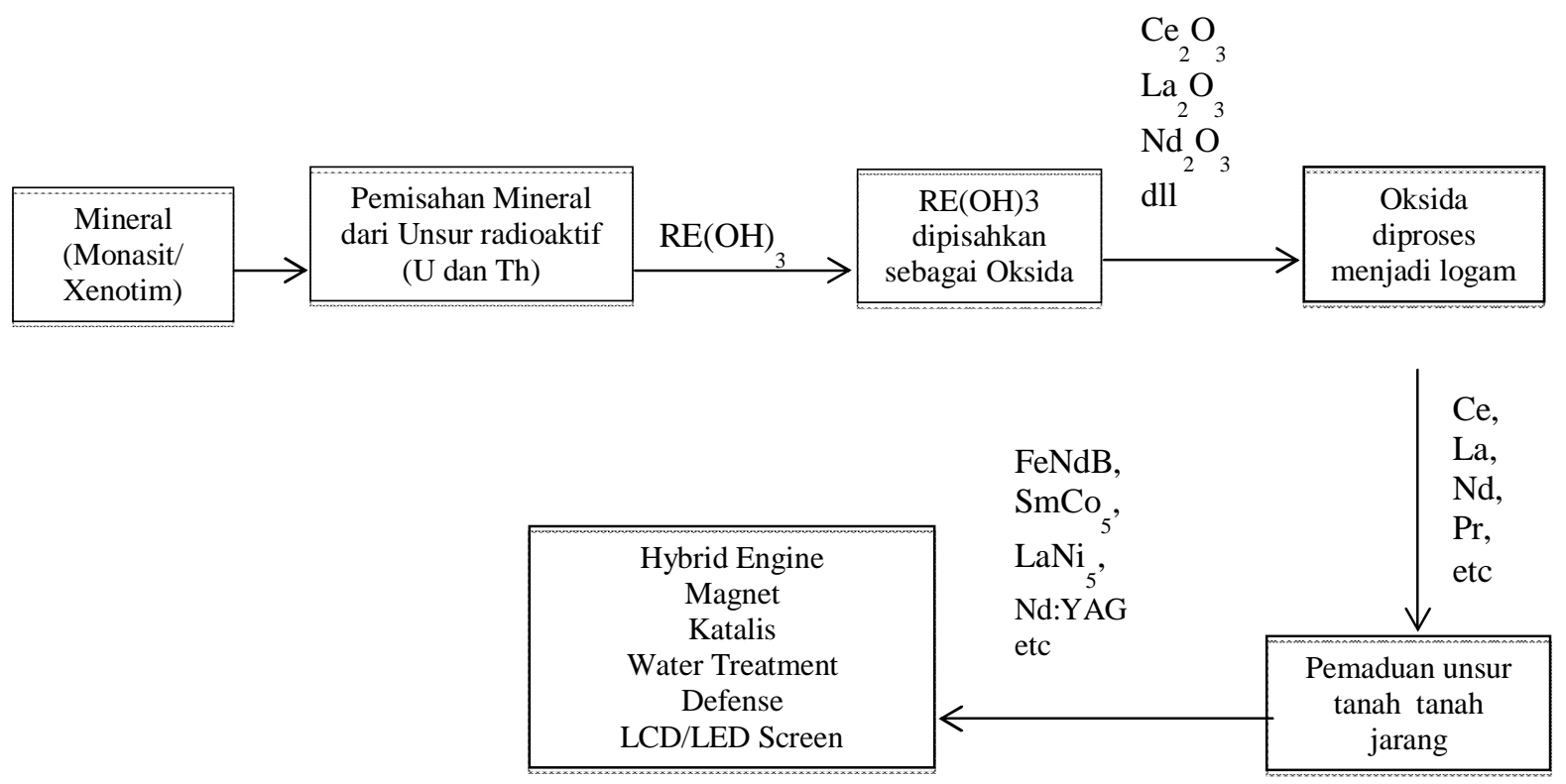

Gambar 6. Flow proses pengolahan tanah jarang dari mineral hingga menjadi produk jadi. 


\section{KESIMPULAN}

Hasil pengujian analisis dari beberapa mineral (selected minerals) menggunakan EDX analisis menunjukkan monasit memiliki ratarata kandungan Ce 28,2 \%, La 12,9\%, Nd $9,7 \%$, Pr 5,2 \%, dan Gd 3,9\%. Sedangkan xentotim mengandung unsur utama Y 29,5\%, Dy $7,7 \%$, dan $\mathrm{Gd} 2,6 \%$. Hasil uji menunjukkan bahwa mineral tanah jarang didapatkan sebagai mineral ikutan dari penambangan timah dan emas. Maka dari itu, pengelolahan lebih lanjut dari mineralineral ikutan agar dimanfaatkan secara optimal dari sumber daya alam yang ada di Indonesia. Selain itu explorasi perlu dilakukan untuk mencari dan mengidentifikasi daerah lain yang memiliki potensi tanah jarang, sehingga pengolahannya bisa lebih ekonomis dengan sumber daya yang lebih besar.

\section{UCAPAN TERIMA KASIH}

Penulis mengucapkan terima kasih kepada PT Timah Tbk, atas fasilitas dan bantuan yang diberikan dalam kegiatan ini, kepada Denny Noviansyah (Pusat Kajian Teknologi BPKIMI, Kemenperin) untuk diskusi dan saran dalam kegiatan penelitian ini.

\section{DAFTAR PUSTAKA}

Asnani, C., \& Patra, R. 2013. Rare Earth from Monazite - Indian Experience. Conference of Metallurgist 2013 (pp. 167-172). Montreal: Canadian Institute of Mining, Metallurgy and Petroleum.

Harjanto, S., Virdhian, S., \& Afrilinda, E. 2013. Characterization of Indonesia rare earth minerals and their potential processing rechniques. Conference of Metallurgist 2013 (pp. 99-108).
Montreal: Canadian Institute of Mining, Metallurgy and Petroleum.

Humphries, M. 2012. Rare Earth Elements THe Global Supply Chain. USA: CRS Report for Congress.

Irawan, S. 2013. Rare Earth Element Mineral Processing in PT Timah Tbk. Workshop on Rare Earth Element Mineral Processing and Refining in Indonesia. Bandung.

Johari, \& Kuntjara, U. 1991. The Occurence of Rare Earth Mineral in Indonesia. Material Science Forum, 645-661.

Kamitani, M. 1991. Proceedings of International Conference on Rare Earth for Electronic Use, (pp. 181-191).

Kanazawa, Y., \& Kamitani, M. 2006. Rare earth minerals and resources in the world. Journal of Alloy and Compound 408-412, 1339-1343.

Ratman, N. 1986. Metalliferous Mineralisation Related to the Geological Environtment in Western Irian Jaya. Buletin of GDRC No. 12 .

Rifandriah et.al., E. 2004. Penentuan Kondisi Dekomposisi Optimal Bijih Uranium Rirang Kalan. PPGN-BATAN.

Suharji et.al. 2006. Peningkatan Kwalitas Estimasi Cadangan Uranium dan Unsur Tanah Jarang Sebagai Asosiasinya di Sektor Rirang Hulu, Kalimantan Barat.

Suhkyat, R. 2013. Potential and Distribution of Indonesia Mineral Resources and Deposits. Seminar on Acceleration Attempts to Increase Domestic Minerals Added Value.

Suwargi, E., \& Nugroho, D. 1991. Hasil Penelitian Logam Jarang di Pegunungan Tiga Puluh Riau. Direktorat Sumberdaya Mineral.

Suwargi, E., Pardiarto, B., \& Ishlah, T. 2010. Potensi Tanah Jarang di Indonesia. Buletin Sumber Daya Geologi Volume 5 Nomor 3, 131-140. 